\title{
Tall Stories: New York Skyscrapers in Art and Literature
} Douglas Tallack*

Abstract: In New York, perhaps more than any other city, skyscrapers have attracted the attention of film-makers, painters, and photographers, and also writers. This essay will concentrate upon the comparatively neglected topic of literary engagements with New York skyscrapers.

In The American Scene (1907), Henry James has difficulty comprehending what these "giants of the mere market" (James 1968: 77) could offer writers, and, especially, novelists and short story writers, and his work is determinedly low-rise. A century later, in Falling Man (2007), Don DeLillo, though much-interested in walking or at least driving the city of New York, confronts the skyscraper more dramatically, still, in the aftermath of the terrorist attack on the World Trade Center. Between The American Scene and Falling Man, writers have sought variously to respond to the challenge which the emerging and complex high-rise visuality of New York City has levelled at formal aspects of fiction, notably perspective and narrative. These formal matters are highlighted by passing comparisons with developments in visual art, which have been stimulated by the marked coincidence of modernism and modernization in New York City.

Keywords: skyscrapers, New York City, modernism, visual art, literature, narrative, perspective.

\footnotetext{
${ }^{*}$ Douglas Tallack is Professor of American Studies, Vice-President (International) and Head of the College of Arts, Humanities and Law at the University of Leicester, UK. His most recent books are New York Sights (2005) and Global Cities/Local Sites (2009), co-edited with Will Straw. Professor Tallack wishes to acknowledge the support of the UK Arts and Humanities Research Council.
} 
From its beginnings in late nineteenth-century America, the skyscraper has been more than a tall building. In "The Tall Building Artistically Considered", published in 1896 , when skyscrapers were fairly recent additions to the American urban scene, Louis Sullivan peremptorily adopts a Whitman-like tone of authority in his account of the structure's aesthetic pedigree. With his landmark Auditorium Building on South Michigan Drive, Chicago, not yet completed, Sullivan had this to say:

... loftiness is to the artist-nature its thrilling aspect. ... It must be tall, every inch of it tall. The force and power of altitude must be in it, the glory and pride of exaltation must be in it. It must be every inch a proud and soaring thing, rising in sheer exultation that from bottom to top it is a unit without a single dissenting line -- that it is the new, the unexpected, the eloquent peroration of most bald, most sinister, most forbidding conditions. (Sullivan 1896: 343)

The skyscraper has gone on into the twentieth-century to carry the weight of being quintessentially "American", along with the gridiron city plan, jazz, mass production, and a few other "inventions", enumerated by John Kouwenhoven (Kouwenhoven 1998: 124-25). Not surprisingly, then, skyscrapers have consistently attracted the attention of painters, photographers, and filmmakers, but also writers. And yet, for all the symbolic potential of the skyscraper as an aspect of American exceptionalism, authors, and particularly novelists and short story writers, have found the writing of "tall stories" and the achievement of a point of view to be more challenging tasks than have visual artists, as they grappled with how best to represent a tall building (see Chave 1991 and Schleier 1990). No writer felt more challenged than Henry James on his return to New York City in 1904, after an absence of twenty years, during which the very tall building had become structurally possible. 
Chicago's pioneering role in skyscraper construction, as Carl Smith has shown, impacted on writers chiefly as a tension between commercial power and democratic promise, with Henry Blake Fuller's The Cliff-Dwellers (1893) central to his thesis (Smith 1984: 121-51). New York City represents a direction in the literary engagement with the skyscraper that is different in degree, rather than kind, though the difference is extreme enough in some cases to warrant attention. From Henry James onwards, New York skyscrapers have provoked some intriguing but, also, dramatic literary interactions with built forms of verticality because of the city's intense geography, but also because New York City increasingly became the city of choice for visual artists. Writers' formal concerns with point of view and narrative were shaped by aesthetic developments, notably a shift from realism to modernism in the years either side of the turn of the century. These concerns were also affected by transformations in the shape of cities, and particularly in New York where modernism and modernization came together in marked ways.

Aside from these possible differences between Chicago and New York, a general claim about tall stories can be made by recalling how easily formal concerns have chimed with any number of literary houses. In the American literary tradition, we can instance such low-rise structures as the House of Usher, the House of the Seven Gables, and the law-office in New York, where Bartleby works and dies, and on to Henry James' house on the "jolly corner", between a cross-street and "the comparatively conservative Avenue" in New York (James 1964: 198). And in English fiction or, rather, with James looking more and more towards England, in Anglo-American fiction, we can instance the Castle of Otranto, Mansfield Park, any number of Dickens' offices, through to James' Gardencourt in The Portrait of a Lady (1881). In sharp contrast, writers have struggled to emulate Louis Sullivan's manifesto on behalf of the tall building. His nationalistic and organicist rhetoric translates uncertainly to narrative, as though it fails to survive the joint onward push of narrative and urban growth from the 
1880 s onwards. Equally, writers seem not to have quite known what to do with Sullivan's materialist focus, neither its engineering nor its functional axis.

Skyscrapers make a troubled early appearance in New York writing in Henry James' The American Scene of 1907, though a much more promising and vivid appearance in American visual art in the 1890s-1910s' period. Similarly, one hundred years later, a skyscraper or, rather, twin skyscrapers, directly provoked a novel, Don DeLillo's Falling Man (2007), and some stories and controversial photographs associated with the figure of the Falling Man, a man falling from the North Tower of the World Trade Center. In different ways, James and DeLillo frame this enquiry because at crucial moments in the city's history and in their respective careers both found skyscrapers awkward to encompass and even to contemplate. This essay will concentrate upon the formal issues precipitated by a select few literary engagements from 1907 to 2007, with different aspects of the emerging and complex high-rise visuality of New York City. These formal issues, notably narrative and perspective, can be highlighted by using visual art as an accompanying counterpoint.

The most vivid paragraphs of The American Scene are devoted to New York City and to skyscrapers, "the element that looms largest for me ... downtown" (James 1968: 80). Encouraged by having known the city very well twenty years earlier, he takes a cruise in the Bay and announces "a sense, through the eyes, of embracing possession" (99). For all his confidence, James' experiences in New York confound him. With his adopted European perspective, he is constantly blocked: he cannot get things, and especially tall buildings, in perspective; indeed, it is tall buildings that deprive him of his geographical and historical bearings. Famously, James reports that his low-rise birthplace in Washington Square has been replaced by a skyscraper which "blocks, at the right moment for its own success, the view of the past" (91). The glass façades of tall buildings repel him, even as he admits that there could be more than meets the eye, if only "downtown" could be "seen and felt from the inside"; if only, he 
intimates, he had not left America so early in his career:

"Felt" - I use that word, I dare say, all presumptuously, for a relation to matters of magnitude and mystery that I could begin neither to measure nor to penetrate, hovering about them only in magnanimous wonder, staring at them as at a world of immovably-closed doors behind which immense "material" lurked, material for the artist, the painter of life, as we say, who shouldn't have begun so early and so fatally to fall away from possible initiations. (James 1968: 80)

James but also his contemporary, Edith Wharton, who was much more of a New York novelist, had difficulty comprehending how tall buildings could generate stories; what could these "monsters of the mere market" offer writers (James 1968: 80)? In his criticism, James famously thinks of his work in architectural terms, but his is a "house of fiction" (James 1962: 46), as is Wharton's, and both authors are determinedly low-rise in their preferences. James' imagination is, typically, spatial and horizontal. Space, in his fiction, can undoubtedly expand imaginatively in a delimited horizontal sphere, as in his house-bound New York Story "The Jolly Corner" (1908). Such expansion meets James' requirement, set out when visiting another horizontal space, College Yard at Harvard, "in which the formal enclosure of objects at all interesting immediately refines upon their interest, immediately establishes values" (James 1968: 62). In the New York chapters of The American Scene, however, James remains nonplussed and upset by skyscrapers which lack limits, and he seems unable to contemplate vertical space as having an interior. Skyscrapers remain objects, without stories.

James' failure of vision when confronted by skyscrapers denotes his period of expatriation in Europe. But, taken literally, his failure is more intriguing because by the time he re-visited the United States, he was a major practitioner of what we now understand as modernism, and, within a few years his Prefaces to the New York Edition had provided a sustained theorization of the concept of point of view. Moreover, within a few years, visual modernism came closest to 
appreciating skyscrapers as a vital part of the built environment of New York City. Two early American modernist paintings are helpful, here. Max Weber's Cubistinspired painting, New York, of 1913, and John Marin's Lower Manhattan (Composing Derived from Top of Woolworth) of 1922 demonstrate what skyscrapers can do for a central tenet of modernism. Two early American modernist paintings are helpful, here. Max Weber's Cubist-inspired painting, New York, of 1913, and John Marin's Lower Manhattan (Composing Derived from Top of Woolworth) of 1922 demonstrate what skyscrapers can do for a central tenet of modernism (see Tallack 2005: plate 6 and figure 5.7).j ${ }^{1}$ Weber re-imagines perspective in a vertical plane, though the intersecting angles and surfaces excitingly confuse top-down, bottom-up and even side-on views of skyscrapers, while the streets and elevated railroad tracks are the lines that criss-cross this urban scene.

John Marin's New York paintings of the 1910s and early 1920s are also much taken with tall buildings. Lower Manhattan (Composing Derived from Top of Woolworth) makes even more dramatic use of foreshortening than does Weber's New York. In Marin's painting it is the tallest building in the world at that time which provides the aerial point of view from which other tall buildings are flattened. As foreshortening flattens the skyscrapers in the vicinity of the Woolworth Building, so they enter spaces which, ordinarily, they do not occupy, and thereby collide with other buildings which are busy escaping their spaces. For all of James' seminal, modernist formulations of point of view, the material dimension of height -- whether looking up or looking down -- is largely absent from his theory of fiction.

In these paintings by John Marin and Max Weber, Cubism meets the city of New York. Many sides of the buildings, in both New York and Lower

\footnotetext{
${ }^{1}$ In addition to these and other cited published sources for the visual works discussed in this essay, readers may make an internet search on the painter's name and the title of the painting.
} 
Manhattan, appear at once, thereby animating space with time. In 1913, the year that Weber painted New York and the Woolworth Building was completed, the European modernist, Francis Picabia, described New York as "the cubist city, the futurist city" (Picabia 1913: 1), and part of the designation was picked up in 1926, with Janet Flanner's novel, The Cubical City. In the case of New York's skyline of tall buildings -- what Henry James called a "pin-cushion in profile" (James 1968: 76) -- Marin and Weber, but also other early American modernists, such as Joseph Stella and Abraham Walkowitz, were trying to paint change and movement. Notwithstanding the circulation in New York City of European modernist theories (as well as European modernists themselves, most controversially Picabia and Marcel Duchamp), the early American modernist artists, as Abraham Davidson classifies them (Davidson 1994), were responding to some striking material changes, to modernization as much as to modernism. The New York skyline was, at once, a startling amalgam of buildings and a phenomenon driven by the power of the market. John Kouwenhowen, who added to the skyscraper in his list of American inventions, "the Manhattan skyline", notes that the "total effect ... is made up of almost innumerable buildings, each in competition ... with all of the others" (Kouwenhoven 1998: 125). The fluctuations on "Wall Street", as the market came to be known, particularly from the 1880 s onwards, could be hourly and certainly daily, and while no built environment could change quite so visibly, monthly change s evident, as tall buildings went up at an incredible pace. Not until the avant-garde modernism of Weber, Marin and others, and the use of fast-motion cinematography, was it possible to read off from the idiosyncratic silhouettes of tall buildings the conclusion that the skyline was the result of many individual enterprises taking place in a congested area but with little appreciation of the construction going on around them; in pictorial terms, there could be no reliable frame. In literary terms, there could be no all-embracing story, and no reliable point of view. 
This is not to say that more conventional writers -- realists in literaryhistorical terms -- did not try to tell the new story of tall buildings in important ways. Willa Cather's story, "Behind the Singer Tower", published in 1912, locates itself in the vicinity of what was, until the Woolworth in 1913, the tallest building in the world. Cather's tall story is about a fire in a skyscraper-hotel, the Mont Blanc Hotel, which killed hundreds of people. Quite understandably, if conventionally for Cather's time and since, the story equates building high with over-reaching ambition. Referring to New York and the United States, the narrator announces that "Our whole scheme of life and progress and profit was perpendicular" (Cather 1912: 16). In The Fountainhead (1943), Ayn Rand would later write the archetypal story of New York architect, Howard Roark, loosely based on Frank Lloyd Wright, the Wright who later planned a "mile-high skyscraper" which was so at odds with the remarkable horizontal modernism of his earlier work. Willa Cather's traditional point of view is apparent in a drawing by George Harding in Collier's which accompanied her story (Cather 1912: 16). It depicts nine workingmen and women looking over a parapet, with the city skyline behind them, organised around the Singer Tower. Everything is in scale and, in spite of the size of the tall buildings in the background, traditional one-point perspective gives depth to the drawing relating every architectural detail to people and the space they occupy in the foreground.

Nevertheless, in "Behind the Singer Tower", Willa Cather is taken by the distortion that seeing New York could provoke. If one reads "Behind the Singer Tower" less for story and more for images, it is surprisingly modernist in the way that metaphors (like the buildings) pile up and tumble over each other:

Those incredible towers of stone and steel seemed, in the mist, to be grouped confusedly together, as if they were confronting each other with a question. ... One might fancy that the city was protesting, was asserting its helplessness, its irresponsibility for its physical conformation, for the direction it had taken. It was an irregular parallelogram pressed between 
two hemispheres, and, like any other solid squeezed in a vice, it shot upward. (Cather 1912: 16)

In much the same way that the characters in William Dean Howells' $A$ Hazard of New Fortunes (1890) are introduced to the spectacle of a city in motion when they travel on the elevated railroad, so Willa Cather's encounter with tall buildings in "Behind the Singer Tower" brings out what can only be described as a modernist appreciation of form. Cather's description of the "incredible towers of stone and steel" may be put alongside a pronouncement from 1911 by John Marin that he would "paint some downtown stuff, and to pile these great houses one upon another with paint as they do pile themselves up here" (Conrad 1984: 128). A Cubist understanding of perspective removes all sense of near and far. The buildings pile up in paint: they collide and create dynamism.

A comparable loss of traditional point of view also occurs in fiction when tall buildings dominate a scene, though it was not until the mid-1920s that fiction started to catch up with the insights of visual modernism. John Dos Passos, in Manhattan Transfer (1925), comes closest to appreciating what was happening both in the streets and in early American modernist paintings whose formal organization had been provoked by the contortions of the skyline. Dos Passos is not an out-and-out modernist but, in describing the tall buildings of Manhattan, he offers us new insights into "steel glass, tile, concrete ... the materials of the skyscrapers. Crammed on the narrow island the millionwindowed buildings will jut, glittering pyramid on pyramid, white cloudheads piled above a thunderstorm" (Dos Passos 2000: 229). Dos Passos follows modernist art and treats the skyscraper as an object, but, rather than echoing Henry James' longing for that "immense 'material' [which] lurked ... for the artist, the painter of life" in the interior, behind its "immovably-closed doors" (James 1968: 80), he looks to the massing of skyscrapers in the wider cityscape, where intersecting planes of buildings, streets, and elevated railroads were doing paradoxical things to space and time (see Beddow 2010, Crickenberger 2005, Spindler 1981, and Tichi 1987). 
The impact of tall buildings, or, rather, the massing of tall buildings in the congested space of Manhattan, starts to influence the form, rather than simply the content, of the city novel. In The American Scene, Henry James adapts his architectural model for fiction to remark, disparagingly, that skyscrapers were stories which only lasted until "another is told" (James 1968: 77). Dos Passos' Manhattan Transfer takes a positive cue from James and imagines a theory of fiction which sees analogies between the structure of tall buildings and the structure of an urban narrative. While the social and political critique which underlies Manhattan Transfer is animated by a desire to put the fallen, modern world back together again, its narrative structure is far from organic, at least in some aspects of its development. For quite lengthy stretches, the narrative is made up of juxtaposed fragments, mini-stories, in effect, and multiple points of view that do not add up. Where James maintains, even of his late texts, that the form of a novel arises from long acquaintance with its characters, in Dos Passos' New York novel, characters are described, in passing, as it were, on a city street. They frequently do not reappear, being provoked by the material form of the city and by the functioning of the market. Horizontal and vertical lines intersect to no larger purpose than that of the market. Dos Passos could well have glimpsed this emerging urban imagination when he visited the Armory Show which, in 1913, announced the arrival of European modernists, particularly Cubists, in New York City.

Janet Flanner's The Cubical City of 1926 does not quite live up to the promise of its title in its efforts to deal with tall buildings, and it is no surprise that John Dos Passos is credited with the most vital formal experiments in New York fiction. The shortcomings of The Cubical City are instructive, though, not least because the central character, Della Porter, is a modernist sketcher of theatre sets: "On the easel before her was a paper smudged with unsettled areas of tentative color and a cluster of inferential black lines" (Flanner 1974: 5). More interestingly, Flanner avoids the moralism and a legacy of organicism that 
distracts Dos Passos from his otherwise remarkable account of the city. She does slip into the by-then clichéd comparisons between Manhattan's profile and mountains or feudal towers, but also catches the key connection with the "financial pattern" of the city downtown, "a force strong enough to have jerked the phenomena of skyscrapers out of the ground" (305), and, uptown, to have created the "compressed pyramided dwellings of New York" (399). However, it is when she elaborates on New York's "nocturnal voltage" (103) and its manifestation of a "mechanical civilization" (315) that she is most acute on the concept of a "cubical city". Returning to the night-time spectacle of New York later in the novel, she remarks on

all that synchronized sinning, all the rehearsed babble off stage, the marching breasts, painted priests, the hundred hired virgins (sopranos), the stars, sub-stars, the blondes, bells, lights, regiment of scene shifters. (Flanner 1974: 239)

Here, Flanner hints at what Siegfried Kracauer terms the "mass ornament", which is central to the "reality present in the stadium patterns" (Kracauer 1995: 85). Market rationalization is basic to the infrastructure of such modern cities as New York and highlighted in its period of skyscraper construction, but is also displayed in the syncopated dance routines which Kracauer analyses in an essay of 1927, and which later reached a pitch in a venue such as Radio City in Rockefeller Center.

While it is only a passing observation, Flanner also catches the association between two of the United States' contributions to modernity. "Jazz", Flanner writes, "was native to an epoch. It was America's national accompaniment to twentieth century Woolworth Gothic" (296). Or in Le Corbusier's formulation: "Hot jazz in stone and steel " (quoted in Kouwenhoven 1998: 127). A little earlier in the novel, Flanner also effects the connection between jazz and the market which, in a sense, produced the New York skyline: 
From a victrola in the corner of the room rose that familiar modern sound of rubber in contact with steel, the friction of two leading quotations on the world's stock market, giving off from this amalgamation (as if even Wall Street had, as esoteric claim for all entities its super-vibration) a type of competitive struggling music, native to a century of newly-rich men with inside information and patented ideas. ... Jazz. (Flanner 1974: 29596).

If a line connecting Henry James with painters such as Max Weber and John Marin and then on to John Dos Passos and Janet Flanner is followed in a more idiosyncratic direction, still, it takes us to the Dutch architect Rem Koolhaas' Delirious New York: A Retroactive Manifesto for Manhattan (1978). The literal description "tall stories" takes on a colloquial meaning in Koolhaas' insight into the excessive quality of New York. Skyscrapers were such extraordinary structures that in visual art and in literature, they often provoked the fantastic, the excessive, almost the unbelievable; in effect, "tall stories" that are far stranger than the phenomenon satirized by Ogden Nash in "A Tale of the Thirteenth Floor":

I have been this way before,

I have cased the joint at every point,

And there is no thirteenth floor.

The architect he skipped direct

From twelve unto fourteen,

There is twelve below and fourteen above,

And nothing in between. (Nash 1957: 142)

In the chapter on "The Skyscraper", Koolhaas speculates on the vertical grids of mid-century New York's minimalist tall buildings, themselves sited on the horizontal street grid-plan:

The Grid's two-dimensional discipline also creates undreamt-of freedom for three-dimensional anarchy. The Grid defines a new balance between 
control and de-control in which the city can be at the same time ordered and fluid, a metropolis of rigid chaos. (1994: 104 and 20)

He discerns a paradoxical logic in which imaginative excess is generated by the repeated rational pattern of the grid. Henry James, speaking through his character Spencer Brydon in "The Jolly Corner", dismisses the grid, yet, in spite of himself, also generates complexity as Brydon seeks out an address:

... the dreadful multiplied numberings which seemed to him to reduce the whole place to some vast ledger-page, overgrown, fantastic, of ruled and cross-crossed lines and figures. (James 1964: 196)

Koolhaas' Delirious New York is a picture book and in the images, as well as in the oxymoronic sentences, skyscrapers are twisted and fractured on the page. The cover image to the first edition, included as a frontispiece to the 1994 edition, depicts the Chrysler Building and the Empire State Building in bed in a room high above the city, looking towards the tip of Manhattan through a gridded window, and with a bedside rug with the design of the street-plan either side of the rectangle of Central Park.

One could select other examples, besides those from James, Dos Passos, Flanner, and Koolhaas to make essentially the same point. On the one hand, modernism in literature is fascinated by visuality: we may recall Joseph Conrad, who was much influenced by Impressionism, announcing that his aim was to make his readers see. But, on the other hand, certain aspects of modern life, including skyscrapers, undermine the power of the eye to put things properly, that is, representationally, in their place. There is even a trope, or rhetorical figure, which describes what is happening, first in visual modernism and then in writing. For Rosalind Krauss:

The opacity that is figured in anamorphosis is a matter of point of view: one can see the image correctly if one can get to the correct position. Whereas the invisibility that arises within modernism is not so obviously physical: it is tinged or affected by the unconscious, and in this 
unconscious invisibility there isn't any correct perspective or other vantage point. It can only be reconstructed in the modality of a different form like language. (Foster 1988: 83-4)

In the case of a novelist such as Henry James, grappling with a truly modern city but equipped with the language of European cities or that of low-rise New York of the 1870 s, the invisibility of modernity amounts to more than the impact of the unconscious on spatial perception. After all, in "The Jolly Corner", what Freud calls the uncanny or the strangely familiar is apparent at every twist and turn of the old house, just as it lies hidden in the labyrinthine interiors of the Waldorf Hotel, as James describes these in The American Scene. But invisibility has a material, physical and startlingly vertical manifestation out on the streets. Describing his experiences in New York on his 1904 visit, James finds that point of view is regularly blocked by tall buildings, as well as being impeded by crowds and traffic. The avenues are too narrow to permit the necessary stepping back to view a tall building. New York in the early twentieth-century was growing with alarming rapidity and in vertical, as well as the more traditional horizontal ways. New York was also different in degree from what the world had seen before. It manifested aspects of modernisation, such as rational systematization and loss of visible contact, which produced striking cross-overs with the concerns of artists grappling with such formal developments as abstraction and arbitrary reference.

To bring this argument up to date, and to present an unexpected twist in the story of tall buildings in American art and literature, it will be helpful to drop back a few years from Rem Koolhaas' speculations on Manhattan to 1947, and a feature on the New York Skyline in Life magazine. Most of the piece is a "photographic essay" by Andreas Feininger, in which, interestingly, his use of a telephoto lens to capture the skyline produces a flat effect, lacking in perspective. The feature ends with a short essay by Winthrop Sargeant. Skyscrapers were a regular theme in semi-popular magazines, and, indeed, it is the familiarity of 
Sargeant's conclusion which offers a clue to the kinds of tall stories that skyscrapers could generate, once writers freed themselves from house-bound, horizontal assumptions. Sargeant, has this to say:

Where the Greek temple and the Gothic cathedral have a quality of religious repose dictated by the proportions of their vaults and pediments, the skyscraper soars upward almost without limit. It has a beginning and perhaps a middle, but its end is an indefinite upward climb. It ends this climb, in fact, not because of any laws of structural logic, but simply because of limits of finance, of engineering, or urban practicability. (Sargeant 1947: 106).

A lack of limits and repetition of identical storeys (meaning the floors of the building, though the pun is illuminating) is presented by Sargeant as a criticism of the lack of variety and interest, and the lack of a form appropriate to the function. Even so, Sargeant's statement is an important insight, if we consider the fate of the World Trade Center, and how it, eventually, found its way into narrative literature. The World Trade Center was, in its way, a classic skyscraper of the second half of the twentieth century because it made a virtue of going on and on, and then doing it again in the second, twin tower. There is no obvious point when the Twin Towers should have stopped. In James' opinion of "the newest mass of multiplied floors and windows" (James 1968: 94) in The American Scene: "One story is good only till another is told, and sky-scrapers are the last word of economic ingenuity only till another word be written" (James 1968: 77). As so often, James is acute in his prejudices.

There was nothing inevitable about the attack on the Twin Towers in 2001 (or in 1993, for that matter), but when it happened the story seemed to have a terrible end. The Towers came down. However, that is when the stories began. The Terrorists had a story, and it survives the killing of Osama Bin Laden. The American Government had a story, and it, too, continues. There were 
thousands of individual stories. And writers began to write post-9/11 stories, almost to the point of forming a sub-genre of contemporary fiction. Don DeLillo's Falling Man (2007) was probably the most anticipated publication because, in the aftermath of $9 / 11$, he had expressed doubts about the future of fiction. In the

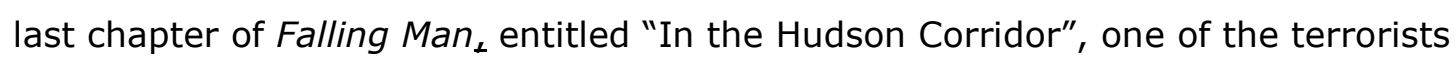
sits facing the passengers, with his back to the direction of flight. He can see nothing of where the plane is headed:

But there was a view, there was a scene of clear imagining out of the back of his head. ... He believed he could see straight into the towers even though his back was to them. He didn't know the aircraft's location but believed he could see straight out the back of his head and through the steel and aluminium of the aircraft and into the long silhouettes, the shapes, the forms, the figures coming closer, the material things. (DeLillo 2007: 238-39).

This man has stopped looking at New York, a city of eight million people, as multi-cultural as one could imagine. In his mind's eye, he is seeing images of martyrdom: "How could any death be better?" he asks, in a chilling conclusion to his story, but "he fastened his seatbelt" (239).

As the plane hits one of the Towers, DeLillo switches the point of view in mid-paragraph to a man in the building. As that man staggers around in the chaos, "something went past the window. Then he saw it. ... He could not stop seeing it, twenty feet away, an instant of something sideways, going past the window, white shirt, hand up, falling before he saw it" (242). This image is repeated in the final sentences of the novel, when the man has escaped from the building: "Then he saw a shirt come down out of the sky. He walked and saw it fall, arms waving like nothing in this life" (246).

The title, Falling Man, refers to a photograph, one of a number of controversial photographs of "the jumpers", so called, taken by Richard Drew, an Associated Press photographer. One photograph has achieved notoriety, simply 
because of the acute particularity of an unknown man caught in mid-air against the mullions of the World Trade Center. This last characteristic is an unnerving sight, as though, in his helplessness, the falling man nevertheless embraces the twin Towers, both soon to fall. He is falling head-first and seems to be looking at the approaching ground. This is a person, plucked out of history by the photograph: it is familiar in the details of his dark trousers, boots and a light-coloured jacket, and also in the well-known verticals of the building, but the context is utterly appalling. The point of Stanley Cavell's comment on photography has never been so devastatingly born out: "What happens in a photograph is that it comes to an end. A photograph is cropped, not necessarily by a paper cutter or by masking but by the camera itself. ... When a photograph is cropped, the rest of the world is cut out. The implied presence of the rest of the world, and its explicit rejection, are as essential in the experience of a photograph as what it explicitly presents" (Cavell 1979: 24). The mullions of the Twin Towers lack perspective. They are flat, as is much modernist art, but their verticality takes us down, with the man. The numbing reality is that we are looking at a photograph of a man who is about to die, and, possibly more shocking, a man who, a moment earlier, had decided to jump.

Richard Drew took some ten sequences of people jumping, a fraction of between fifty and two hundred people who jumped to their deaths that day. The photograph of the man falling and upside down, poised at the vertical divide between the North and South Towers, was the one to go round the world, as a shot once went round the world and started a national epic. Drew's photograph usually appeared a single time in newspapers but, along with his other photographs of the jumpers, was then dropped, as though to use the photograph was to exploit a man's death and risk that his family or friends would recognize him, itself a painful enough experience but associated, it seems, with the idea that the jumpers were somehow cowards. The story ran and ran, even when the photograph had been, in effect, self-censored. One family denied it was their 
father/husband/brother on the basis that their loved one would never have jumped. However, another family embraced the falling man, taking his action as heroic, even as an impossible attempt to return to them, as though the verticals could lift him free of the ground (see Junod 2003).

In his article, "In the Ruins of the Future", written soon after the attack, DeLillo seems to wonder, amidst all the stories, whether fiction could add anything to what had been seen and experienced on the $11^{\text {th }}$ of September, 2001. The destruction of the Twin Towers was a far-more dramatic challenge to formed and shaped narrative than that faced by Henry James when he gazed at New York City on his return in 1904, though different in degree not kind, when allowances are made for available formal and cultural resources. In The American Scene, as has often been noticed, James manages to write in compelling terms about New York's skyscrapers, even though they represented the most blatant affront to his urban sensibility. Turning the skyscraper into a new kind of habitable house of fiction seemed beyond him, though. Writers in the first few decades of the twentieth century needed to get beyond the skyscraper as a symbol of either American success or over-reaching failure, and work in the language of mechanization in order to come up with different kinds of characters, narratives and perspectives upon the city. Dos Passos' Manhattan Transfer is the apogee of this coming to terms with the skyscraper. To this extent, the rush of novels about the shocks of 1980s hyper-consumption and its effects in New York by Tom Wolfe, Jay McInerney, Brett Eason Ellis and others return to earlier themes, but without emulating his insights into the difference that building tall makes to narrative form.

In Don DeLillo's case, the Twin Towers did provoke a novel which arises from his own misgivings. The Twin Towers and the awful first day appear and disappear in the novel, as does a performance artist who suspends himself from buildings in the "pose" of the falling man of Richard Drew's photograph. The 
stories of a number of connected and disconnected characters recall Dos Passos' technique, but, in the city after $9 / 11$ these stories take on a tragic everyday quality. DeLillo's novel, Falling Man joins the many other stories that became a wake for buildings which had, hitherto, only gradually won New Yorkers' affection, and little of DeLillo's in Players (1977). These are the "counternarratives" speculated upon in "The Ruins of the Future", the stories which followed the destruction of New York's tallest buildings. They appeared in newspapers, on television and radio, on web-sites, and on temporary postings on buildings seeking news of lost people.

\section{Works Cited}

Beddow, Alastair. "Manhattan Nightmares: John Dos Passos, Charles Sheeler and the Distortion of Urban Space." Moveable Type, 6, 2010: 1-12. http://www.ucl.ac.uk/english/graduate/issue/6/pdfs/ArticleBeddowManhattanNightmares.pdf

Brooker, Peter. New York Fictions: Modernity, Postmodernism, The New Modern. London: Longman, 1996.

Cather, Willa. "Behind the Singer Tower." Collier's, 49, May 18, 1912: 16-17, 41. http://cather.unl.edu/cat.ss045/cat.ss045.001.jpg

Cavell, Stanley. The World Viewed: Reflections on the Ontology of Film, enlarged edition. Cambridge, Massachusetts: Harvard University Press, 1979.

Chave, Anna C. "'Who Will Paint New York?': 'The World's New Arts Center' and the Skyscraper Paintings of Georgia O'Keeffe." American Art, 5, 1-2, Winter-Spring 1991: 87-107.

Conrad, Peter. The Art of the City: Views and Versions of New York. New York: Oxford University Press, 1984.

Crickenberger, Heather Marcelle. "Passengers: John Dos Passos' Manhattan Transfer." The Arcades Project Project or The Rhetoric of Hypertext, 2005: chapter 11. http://www.thelemming.com/lemming/dissertation- 
web/home/passengers.html. This web-project is part of Heather Marcelle Crickenberger, "The Structure of Awakening: Walter Banjamin and Progressive Scholarship in New Media", PhD thesis, University of South Carolina, 2007.

Davidson, Abraham S. Early American Modernist Painting, 1910-1935. New York: Da Capo Press, 1994.

DeLillo, Don. Falling Man: A Novel. London: Picador, 2007.

DeLillo, Don. "In the Ruins of the Future: Reflections on Terror and Loss in the Shadow of September". Harper's Dec ember, 2001: 33-40.

Dos Passos, John. Manhattan Transfer. London: Penguin Books, 2000.

Flanner, Janet. The Cubical City. Carbondale, Illinois: Southern Illinois University Press, 1974.

Foster, Hal. Vision and Visuality. Seattle: Bay Press, 1988.

James, Henry. The American Scene. Bloomington, Indiana: Indiana University Press, 1968.

James, Henry. The Art of the Novel: Critical Prefaces. New York: Charles Scribner's Sons, 1962.

James, Henry. "The Jolly Corner". The Complete Tales of Henry James, ed., Leon Edel. London: Rupert Hart-Davis, 1964: 193-232.

Junod, Tom. "The Falling Man." Esquire, September 8, 2003. http://www.esquire.com/features/ESQ0903-SEP FALLINGMAN.

Koolhaas, Rem. Delirious New York: A Retroactive Manifesto for Manhattan. New York: Monacelli Press, 1994

Kouwenhoven, John A. "What's 'American' About America". The Jazz Cadence of American Culture, ed., Robert G. O'Meally. New York: Columbia University Press, 1998: 123-36.

Kracauer, Siegfried. The Mass Ornament: Weimar Essays, trans. Thomas Y. Levin. Cambridge, Massachusetts: Harvard University Press, 1995.

Nash, Ogden. You Can't Get There From Here. London: Dent, 1957. 
Rand, Ayn. The Fountainhead. Chicago: Bobbs-Merrill, 1943.

Francis Picabia, "A Post-Cubist's Impression of New York." New York Tribune, 9th March 1913: 1 .

Sargeant, Winthrop. "The New York Skyline: Our Skyscrapers. Life, March 31, 1947: 106.

Schleier, Merrill. The Skyscraper in American Art, 1890-1931. New York: Da Capo Press, 1990.

Smith, Carl, S. Chicago and the American Literary Imagination, 1880-1920. Chicago: University of Chicago Press, 1984.

Spindler, Michael. "John Dos Passos and the Visual Arts," Journal of American Studies 15 Dec. 1981: 391-405.

Sullivan, Louis. "The Tall Building Artistically Considered." Lippincott's Magazine, 57, March 1896: 403-09. http://www.gwu.edu/ art/Temporary SL/177/pdfs/Sullivan Tall.pdf

Tichi, Cecelia. Shifting Gears: Technology, Literature, Culture in Modernist America. Chapel Hill, North Carolina: University of North Carolina Press, 1987. 